
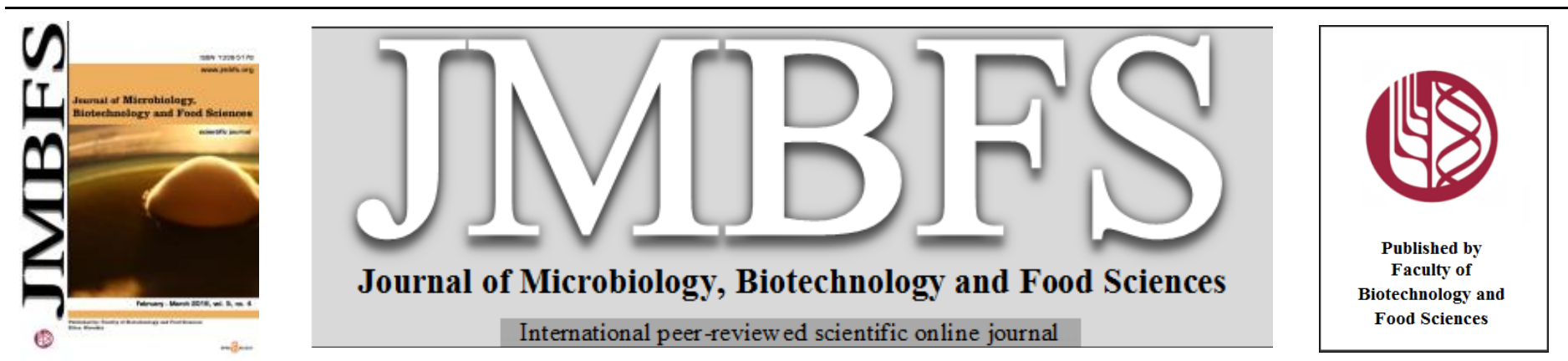

\title{
ISOLATION AND IDENTIFICATION OF GOAT MILK-DERIVED Lactobacillus paracasei M104 AND Pediococcus pentosaceus M103 AND THEIR POTENTIAL USE AS STARTER CULTURE FOR FERMENTATION
}

\author{
Widodo $^{* 1,2}$, Indratiningsih ${ }^{1}$, Nurliyani ${ }^{1}$, Endang Wahyuni ${ }^{1}$ and Tiyas Tono Taufiq ${ }^{2}$ \\ Address(es): Widodo, $\mathrm{PhD}$ \\ ${ }^{1}$ Universitas Gadjah Mada, Faculty of Animal Science, J1. Fauna No. 3, Bulaksumur, Yogyakarta 55281, Indonesia, phone number: +62-274-513363. \\ ${ }^{2}$ Universitas Gadjah Mada, Research Centre for Biotechnology, Jl. Teknika Utara, Bulaksumur, Yogyakarta 55281, Indonesia.
}

*Corresponding author: widodohs@ugm.ac.id

doi: 10.15414/jmbfs.2016.5.5.374-377

\section{ARTICLE INFO}

Received 25. 4. 2015

Revised 16. 11. 2015

Accepted 2. 12. 2015

Published 1. 2. 2016

Regular article

OPEN $\partial_{\text {AcCESS }}$

\begin{abstract}
The aims of this study were to isolate and identify lactic acid bacteria from the fresh milk of crossbred Peranakan Etawah goats in Yogyakarta, Indonesia and assess their potential utility in dairy fermentation. Fresh milk samples were collected from three different farms and plated into de Man Rogosa and Sharpe (MRS) agar supplemented with $0.5 \%$ ox bile. Colonies were purified with a streaking method followed by morphological and biochemical analysis using Gram staining, a catalase test, tests of motility and spore formation and growth at different temperatures. Molecular identification was based on nucleotide sequencing of 16S rRNA genes. Four isolates, M101, M102, M103 and M104, were identified. Certain features of isolates M101 and M102 were homologous with Lactococcus garvieae, isolates M103 and M104 showed a degree of homology with Pediococcus pentosaceus and Lactobacillus paracasei subsp. paracasei respectively. Selected isolates were used to ferment milk at $37^{\circ} \mathrm{C}$ for 10 hours. After $10 \mathrm{~h}$, milk fermented with Lactobacillus paracasei M104 had a pH of 4.21 \pm 0.07 and acidity of 1.13 \pm 0.05 . Milk fermented with Pediococcus pentosaceus M103 had a pH of $4.34 \pm 0.03$ with acidity of $1.18 \pm 0.05$. Lactococcus garvieae had limited ability to acidify milk, producing only a slight change in $\mathrm{pH}$ over $10 \mathrm{~h}$. There was no significant difference $(\mathrm{P}>0.05)$ in viscosity between milk fermented with Lactobacillus paracasei M104 and milk fermented with Pediococcus pentosaceus M103. Total viable cells were similar between milk fermented with Lactobacillus paracasei M104 and milk fermented with Pediococcus pentosaceus. On the basis of their capacity to acidify milk, Pediococcus pentosaceus M103 and Lactobacillus paracasei M104 were selected for further investigation.
\end{abstract}

Keywords: Goat milk, lactic acid bacteria, molecular identification, fermentation

\section{INTRODUCTION}

Goat farming is an attractive enterprise for small-scale farmers in developing countries and those working sub-prime agricultural land (Pirisi et al., 2007) as goats are well-adapted to grazing on poor or marginal land. The capacity for both meat and milk production is another benefit. The main use of goat milk is for cheese-making in small local dairies, particularly in Mediterranean and south-east European countries, although there are also some big cheese factories in Western Europe (Pirisi et al., 2007). Goat milk can be used as a substitute for cow milk in cases of allergy to bovine milk (Kongo et al.,1996). To date goat milk has been fermented using lactic acid bacteria (LAB) as a starter culture (del Campo et al., 2005). In Indonesia, goat milk has been used for cheese production based on LAB as starters obtained from commercial sources. A number of LAB species have been used for milk fermentation, for example Lactococcus lactis in cheese production and Lactobacillus casei for souring milk. LAB species used in Indonesian dairy productions are usually isolated from gastrointestinal tract (GIT) or from food products; there have been no reports of use of LAB isolated from local goat milk.

LAB are frequently associated with food and feed fermentation (Axelsson, 2004). $\mathrm{LAB}$ species are indigenous to food habitats such as plant-derived products and milk environments. LAB are also naturally associated with the animal mucosae, including the mucosae of the small intestine, colon and vagina. The same LAB species are frequently isolated from diverse sources, implying wide distribution and adaptation to a range of environments (Makarova et al., 2006). During fermentation LAB produce organic acids, mainly lactic acid and acetic acid, that decrease $\mathrm{pH}$ and increase acidity thus causing rapid acidification of fresh milk. This produces fermented milk products with low $\mathrm{pH}$, such as yoghurt, sour milk and other products. Fermenting milk increases the availability of its nutrients. The aim of this study was to isolate and identify LAB from the fresh milk of crossbred Peranakan Etawah (PE) goats, and evaluate their potential for use as starter culture in milk fermentation.

\section{MATERIALS AND METHODS}

\section{Fresh milk preparation, bacterial isolation and identification}

Fresh goat milk samples were obtained from three different farms in Yogyakarta, Indonesia. Fresh milk was cooled immediately after milking in an ice box and transported to the laboratory for analysis. An $1 \mathrm{ml}$ aliquot of fresh goat milk was added to $9 \mathrm{ml}$ of $0.1 \%$ (w/v) sterile peptone water to obtain $10^{-1}$ dilution. After three-fold serial dilution $0.1 \mathrm{ml}$ aliquots were surface plated on de Man Rogosa and Sharpe (MRS) agar (Merck) supplemented with $0.15 \%(\mathrm{w} / \mathrm{v})$ ox bile then incubated anaerobically at $37^{\circ} \mathrm{C}$ for 48 hours. White colonies visible on the plate after incubation were subjected to morphological and physiological analysis, including Gram staining, a catalase test, assessments of shape, spore formation, motility and $\mathrm{CO}_{2}$ and $\mathrm{NH}_{3}$ production and comparison of growth at $10^{\circ} \mathrm{C}$ and $45^{\circ} \mathrm{C}$. These screening tests were used to select colonies with LAB characteristics which were then subjected to molecular identification using 16S rRNA gene amplification.

\section{Amplification of 16S rRNA gene}

Amplification of a 518bp fragment of $16 \mathrm{~S}$ rRNA gene was carried out using PCR with primers based on the conserved region of 16S rRNA gene, namely a forward primer $p l b 16$ (5-AGAGTTTGATCCTGGCTCAG-3) and a reverse primer $m l b 16$ (5-GGCTGCTGGCACGTAGTTAG-3) (Martin et al., 2009). Gene amplification was performed using a PCR thermal cycler. The PCR protocol was as follows: denaturation at $95^{\circ} \mathrm{C}$ for $30 \mathrm{~s}$, annealing at $56^{\circ} \mathrm{C}$ for $30 \mathrm{~s}$, elongation at $72^{\circ} \mathrm{C}$ for $45 \mathrm{~s}$ ( 30 cycles) and a final extension at $72^{\circ} \mathrm{C}$ for $10 \mathrm{~min}$. Amplified bands were resolved by electrophoresis in $1.6 \%(\mathrm{w} / \mathrm{v})$ agarose gels and visualised using ethidium bromide staining. 


\section{DNA sequencing and phylogenetic analysis}

The amplified DNA was sequenced using an Applied Biosystem 3730-XL Analyser at $1^{\text {st }}$ Base Sequencing, Kuala Lumpur, Malaysia. The resulting sequences were used to search the National Centre for Biotechnology Information (NCBI) database using the Basic Local Alignment Search Too (BLAST) algorithm; the isolates were identified on the basis of the sequences which produced the best match $(>97 \%)$. Molecular Evolutionary Genetics Analysis (MEGA) 6.0 was used to construct a phylogenetic tree of the sequences based on the neighbour-joining algorithm (Saitou \& Nei, 1987).

\section{Milk fermentation}

Fresh milk was pasteurised at $85^{\circ} \mathrm{C}$ for $30 \mathrm{~min}$, followed by cooling to $37^{\circ} \mathrm{C}$. Pasteurised milk was inoculated with bacterial cultures $(2 \% \mathrm{v} / \mathrm{v})$ and thoroughly stirred. The inoculated milk was incubated at $37^{\circ} \mathrm{C}$ for $10 \mathrm{~h} ; \mathrm{pH}$ and acidity were analysed every 2 hours during the fermentation period. The $\mathrm{pH}$ value of the fermented milk was measured with a $\mathrm{pH}$ meter (Hanna model, Romania). Titratable acidity was measured as percentage lactic acid by titrating $0.1 \mathrm{~N}$ of $\mathrm{NaOH}$ using phenolphthalein as indicator (Hadiwiyoto, 1994). The titration method (AOAC Official Method, 1995) was used for lactose analysis.

\section{Apparent viscosity and syneresis}

The apparent viscosity of samples was analysed at $29^{\circ} \mathrm{C}$ using the procedure described by Tuncturk (2009) using a Brookfield digital rheometer model DV III (Brookfield Engineering Laboratories Inc., Massachusetts, USA) with spindle numbers 62 and 63, spindle speed $60 \mathrm{rpm}$. Syneresis was measured using centrifugation (Keogh and O'Kennedy, 1998). A $15 \mathrm{~g}$ aliquot of sample was centrifuged at $1500 \mathrm{rpm}$ for $20 \mathrm{~min}$ at $4^{\circ} \mathrm{C}$. The supernatant was collected and weighed and the extent of syneresis was calculated using following equation:

Syneresis $(\%)=\quad \frac{\text { Weight of supernatant }(\mathrm{g})}{\text { Weight of sample }(\mathrm{g})} \times 100 \%$

\section{Total viable cells}

An $1 \mathrm{ml}$ aliquot of fermented milk was collected from all samples. Aliquots were diluted seven-fold in a sterile solution of $0.85 \%(\mathrm{w} / \mathrm{v}) \mathrm{NaCl}$, then plated onto MRS agar and incubated at $37^{\circ} \mathrm{C}$ for 24 to $48 \mathrm{~h}$. The colonies were then counted and total bacterial numbers per sample were estimated.

\section{Lactic acid concentration using High Performance Liquid Chromatography} (HPLC)

Lactic acid measured using HPLC was carried out according to the procedure described by Bevilacqua and Califano (1989) using a reverse-phase C8 column at room temperature, a mobile phase of $0.5 \%$ w/v buffer $\left(\left(\mathrm{NH}_{4}\right)_{2} \mathrm{HPO}_{4}\right.$ at $\mathrm{pH} 2.24$ with $\left.\mathrm{H}_{3} \mathrm{PO}_{4}\right)-0.4 \%(\mathrm{v} / \mathrm{v})$ acetonitrile and $1.2 \mathrm{~mL} / \mathrm{min}$ flow rate with $\mathrm{UV}$ detection at $214 \mathrm{~nm}$.

\section{Data analysis}

Data on $\mathrm{pH}$, acidity, lactose content, lactic acid concentration, viscosity and syneresis were analysed statistically using paired $T$-tests with statistical significance accepted at $P<0.05$.

\section{RESULTS AND DISCUSSION}

\section{Bacterial Identification and Selection}

We obtained 4 isolates with the morphological and physiological characteristics of LAB (Table 1). LAB are usually characterised as Gram-positive, aerobic or facultative anaerobic, non-motile asporogenous rods and cocci with the ability to ferment carbohydrate with lactic acid as the main fermentation product (Franz $e$ al., 2010). Preliminary identification was based on morphological and physiological analysis, ability to produce $\mathrm{CO}_{2}$, growth at different temperatures $\left(10^{\circ} \mathrm{C}, 37^{\circ} \mathrm{C}\right.$ and $\left.45^{\circ} \mathrm{C}\right)$, pHs (4.4 and 9.6) and in media containing $6.5 \% \mathrm{NaCl}$. The characteristics of all isolates are presented in Table 1.

Table 1 Morphological and biochemical identification of isolates

\begin{tabular}{|c|c|c|c|c|c|c|c|c|c|}
\hline \multirow{2}{*}{ Isolates } & \multirow{2}{*}{ Form } & \multirow{2}{*}{$\mathrm{CO}_{2}$} & \multicolumn{3}{|c|}{ Growth temperature } & \multirow{2}{*}{$\mathrm{NaCl} 6.5 \%$} & \multicolumn{2}{|c|}{ Growth pH } & \multirow{2}{*}{ Genus* } \\
\hline & & & $10^{\circ} \mathrm{C}$ & $37^{\circ} \mathrm{C}$ & $45^{\circ} \mathrm{C}$ & & 4.4 & 9.6 & \\
\hline M101 & Cocci & - & - & + & + & - & + & - & Pediococcus \\
\hline M102 & Cocci & - & - & + & + & + & - & - & Lactococcus \\
\hline M103 & Cocci & - & - & + & + & - & + & - & Pediococcus \\
\hline M104 & Bacilli & - & - & + & + & + & + & - & Lactobacillus \\
\hline
\end{tabular}

* Based on Axelsson's (2002) classification of LAB.

Comparison of the fermentation patterns of all isolates with Axelsson's (2002) classification of LAB resulted in identification of three genera of LAB; M101 and M103 were identified as Pediococci, M102 as Lactococcus and M104 as Lactobacillus (Table 1). All isolates were homofermentative without $\mathrm{CO}_{2}$ production and isolates M101 and M103 were intolerant of salt $(\mathrm{NaCl} 6.5 \%) .16 \mathrm{~S}$ rRNA gene sequencing suggested that isolates M101 and M102 were close homologues (97\% similarity) of Lactococcus garvieae strain 29; isolate M103 was a close homologue ( $96 \%$ similarity) of Pediococcus pentosaceus strain LAB6 and isolate M104 was a close homologue (97\% similarity) of Lactobacillus paracasei subsp. paracasei strain X212 (Figure 1).

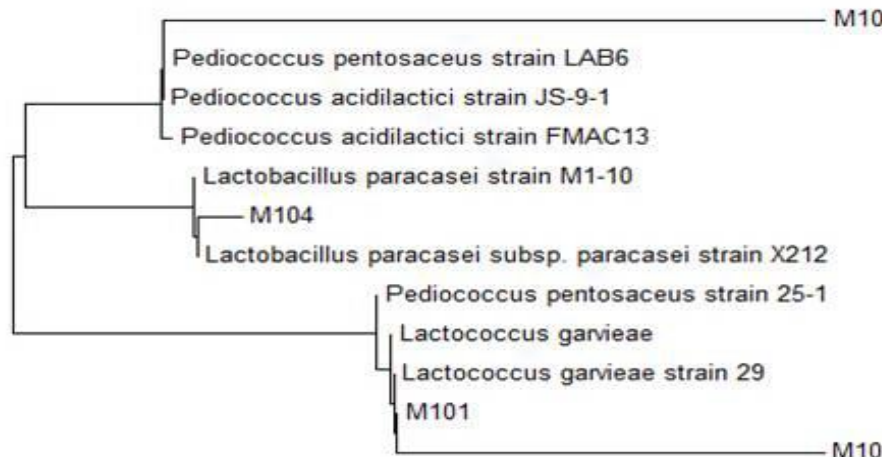

\subsection{5}

Figure 1 Phylogenetic tree showing the genetic relationship of selected isolates to other $\mathrm{LAB}$

This study identified $L$. garvieae, $P$. pentosaceus and $L$. paracasei in fresh milk from crossbred Peranakan Etawah goats in Indonesia. L. garvieae is often associated with fermented dairy products; Morea, Baruzzi and Cocconcelli (1999) have previously reported its presence in goat milk. L. garvieae is one of main bacterial populations in traditional production of mozzarella-type cheese from goat milk and forms part of the autochthonous bacterial population in various Italian and Greek cheeses (Fortina et al., 2007). L. garvieae has also been reported to occur in the milk of Kabyle goats from Algeria (Badis et al., 2004) This study reports the presence of $L$. garvieae in fresh milk from crossbred Peranakan Etawah goats.

$P$. pentosaceus is part of the natural microflora of vegetables and dairy products (Carraro et al., 2011) and has also been found in human breast milk (Osmanagaogl et al., 2013). P. Pentosaceus appears to be a good candidate as starter culture for dairy fermentation as it grows well at $45^{\circ} \mathrm{C}$, is homofermentative and has a long history as being safe for consumption. In other reports, $P$. pentosaceus isolated from traditional dairy products was good at curdling milk.

L. paracasei has previously been isolated from goat milk (Badis et al., 2004) This species has been used as starter culture for probiotic fermented milk (Kristo et al., 2003; Patrignani et al., 2009). It inhibits the activity of yeasts on the surface of dairy products such as yoghurt or cheese at refrigerator temperatures $\left(6^{\circ} \mathrm{C}\right)$ without an influencing their quality (Schwenninger and Meile, 2004)

\section{Acidification Capability}

The acidifying capacity of the selected isolates was evaluated by using them to inoculate individual samples of sterile skimmed milk $(18 \% \mathrm{w} / \mathrm{v})$ and incubating at $37^{\circ} \mathrm{C}$ for $10 \mathrm{~h}$. P. pentosaceus M103 and L. paracasei M104 exhibited fas acidification activity (Figures 2 and 3), whereas L. garvieae M101 and M102 exhibited slow acidification activity (data not shown). The $\mathrm{pH}$ and acidity of milk samples inoculated with $L$. paracasei M104 and P. pentosaceus M103 during fermentation are presented in Figures 2 and 3, respectively. At the final $\mathrm{pH}$ measurement, isolates $L$. garvieae M101 and M102 had pHs of $5.18 \pm 0.12$ and $5.24 \pm 0.17$ respectively, whilst fermentation using $P$. pentosaceus $\mathrm{M} 103$ and $L$ paracasei M104 resulted in samples with pHs of $4.34 \pm 0.03$ and $4.21 \pm 0.07$ respectively (Figure 2). 


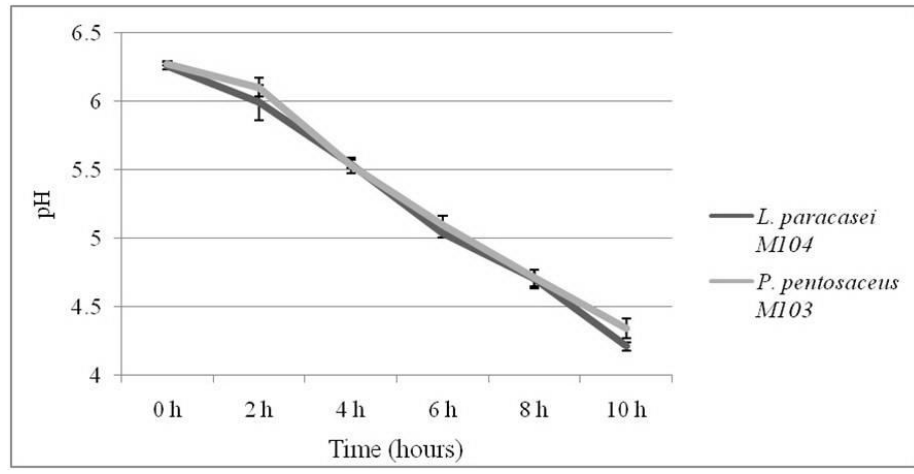

Figure 2 Changes in $\mathrm{pH}$ during incubation with different starter cultures

Figure 2 showed that during fermentation $\mathrm{pH}$ decreased gradually whilst acidity increased significantly $(P<0.05)$ (Figure 3$)$. The acidity of milk fermented with L. paracasei M104 increased from $0.31 \% \pm 0.01$ to $1.13 \pm 0.05$ and the acidity of milk fermented with $P$. pentosaceus $\mathrm{M} 103$ increased from $0.31 \% \pm 0.01$ to $1.18 \pm$ 0.05 (Figure 3); milk fermented with $L$. paracasei M104 or P. pentosaceus M103 had similar acidity and $\mathrm{pH}$ values.

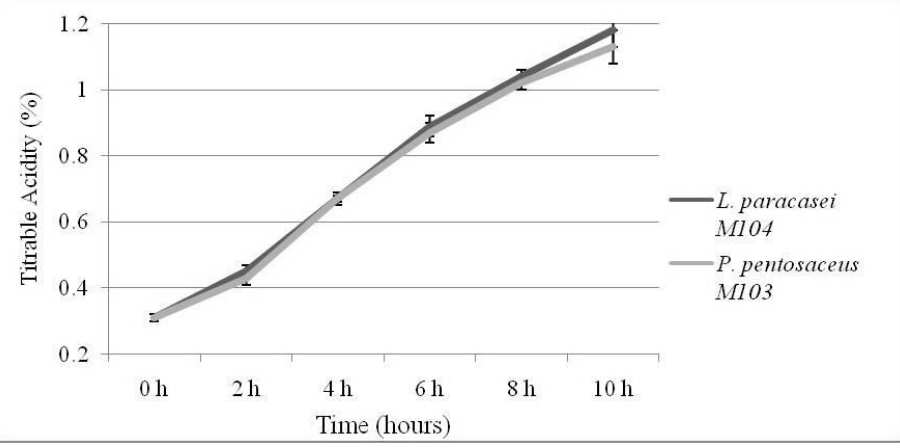

Figure 3 Changes in acidity during incubation with different starter cultures

According to Robinson (2002), acidification is the main indicator of the progress of fermentation. LAB produce organic acids from lactose enzymatically, resulting in formation of curds with distinctive flavours. In this study lactose content and lactic acid concentration were measured before and after fermentation (Table 2). During fermentation the lactose content of milk decreased from $4.6 \% \pm 0.39$ to $3.15 \% \pm 0.35$ when fermented with $L$. paracase M104, and from $4.6 \% \pm 0.39$ to $3.2 \% \pm 0.22$ when fermented with $P$. pentosaceus M103 (Table 2), whilst the lactic acid concentration increased from $0.1422 \% \pm 0.021$ to $0.1905 \% \pm 0.0145$ and from $0.1422 \% \pm 0.021$ to $0.1768 \% \pm$ 0.034 during fermentation with $L$. Paracasei M104 and P. pentosaceus M103 respectively (Table 2 ).

Table 2 Changes in lactose content (\%) and lactic acid (\%) after $10 \mathrm{~h}$ fermentation

\begin{tabular}{lccc}
\hline Starter Culture & $\begin{array}{c}\text { Time } \\
\text { (hour) }\end{array}$ & Lactose (\%) & Lactic Acid (\%) \\
\hline L. paracasei M104 & 0 & $4.60 \pm 0.39^{\mathrm{a}}$ & $0.1422 \pm 0.0210^{\mathrm{b}}$ \\
& 10 & $3.15 \pm 0.35^{\mathrm{b}}$ & $0.1905 \pm 0.0145^{\mathrm{a}}$ \\
\hline P. pentosaceus M103 & 0 & $4.60 \pm 0.39^{\mathrm{a}}$ & $0.1422 \pm 0.0210^{\mathrm{b}}$ \\
& 10 & $3.24 \pm 0.22^{\mathrm{b}}$ & $0.1768 \pm 0.034^{\mathrm{a}}$ \\
\hline
\end{tabular}

Values expressed as mean \pm standard deviation of three replicates

Means within each column with different superscript letters indicate statistically significant differences $(\mathrm{P}<0.05)$

The increase in acidity during fermentation resulted in coagulation of proteins and curd formation, leading to increased viscosity and syneresis. We therefore measured apparent viscosity and syneresis after fermentation; these data are presented in Table 3. Before fermentation milk had a viscosity of $1.82 \mathrm{cP} \pm 0.12$ (Table 3). Milk fermented with $P$. pentosaceus M103 had significantly $(P<0.05)$ higher apparent viscosity than milk fermented with $L$. paracasei M104 $(1475 \mathrm{cP} \pm$ 15 and $1075 \mathrm{cP} \pm 25$ respectively, at the end of the fermentation period) (Table 3 ). There were no significant differences $(P>0.05)$ in syneresis between milk fermented with $L$. paracasei M104 or P. pentosaceus M103 (84.94\% \pm 1.6 and $84.94 \% \pm 2.2$ respectively) (Table 3 ).

Table 3 Viscosity (cP) and syneresis (\%) before and after fermentation

\begin{tabular}{lccc}
\hline \multirow{2}{*}{ Starter culture } & \multicolumn{2}{c}{ Viscosity } & Syneresis \\
\cline { 2 - 3 } & $0 \mathrm{~h}$ & $10 \mathrm{~h}$ & $(10 \mathrm{~h})$ \\
\hline L. paracasei M104 & $1.82 \pm 0.12^{\mathrm{a}}$ & $1075 \pm 25^{\mathrm{b}}$ & $84.94 \pm 1.6$ \\
P. pentosaceus M103 & $1.82 \pm 0.12^{\mathrm{a}}$ & $1475 \pm 15^{\mathrm{c}}$ & $84.94 \pm 2.2$ \\
\hline Vannnn
\end{tabular}

Values expressed as mean \pm standard deviation of three replicates
Means within each column with different superscript letters indicate statistically significant differences $(\mathrm{P}<0.05)$

Starter cultures can be defined as a microbial biomass, consisting of a large number of cells in the logarithmic phase of growth, which can be added to raw food products to accelerate fermentation processes (Leroy and De Vuyst, 2004). $P$. pentosaceus M103 and L. paracasei M104 (Figures 2 and 3) showed fast acidification activity, whereas $L$. garvieae M101 and M102 showed slow acidification activity (data not shown). The primary function of LAB in industrial dairy fermentation is use of lactose (de Vos and Vaughan, 1994). Lactic acid accumulation decreases $\mathrm{pH}$ and improves the acidity of products. Fermented dairy products usually have a $\mathrm{pH}$ of 4.6 or lower (Chandan, 2006). In this study products fermented with $L$. garvieae M101 and M102 had pHs of no $4.34 \pm 0.03$ and $4.21 \pm 0.07$, respectively (Figure 2), i.e. within the required range. A previous study (Widodo et al., 2014) reported that $\mathrm{pH} 4.5$ was achieved after 5 hours of goat milk fermentation using mono-species starter cultures of Lactobacillus acidophilus FNCC-0029 or Lactobacillus casei FNCC-0051. In this study a $\mathrm{pH}$ of 4.5 was obtained after 9 hours of fermentation with $P$. pentosaceus M103 or L. paracasei M104 as starter, indicating that fermentation with these species was slower than that of Lactobacillus acidophilus FNCC-0029 or Lactobacillus casei FNCC-0051. The final acidities of milk fermented with $L$. paracasei M104 or P. pentosaceus M103 were $1.13 \% \pm 0.05$ and $1.18 \% \pm 0.05$ respectively (Figure 3), within the range of the Indonesian national standard (SNI), 0.5 to 2.0\% (Badan Standarisasi Nasional, 1998).

Higher acidity stimulates syneresis, thereby improving the viscosity of fermented dairy products (Tamime and Robinson, 1999). In this study use of $P$. pentosaceus M103 or L. paracasei M104 for milk fermentation resulted in products with the same final acidity (Table 2), but different viscosities (Table 3). Keogh and O'Kennedy (1998) suggested that differences in viscosity are probably due to variations in protein ratios or ion values, and may also be affected by incubation and storage conditions.

\section{Total Viable Cells}

Data on the numbers of viable L. paracasei M104 and P. pentosaceus M103 before and after fermentation are presented in Table 4. At the end of fermentation there was no significant difference $(\mathrm{P}>0.05)$ in the number of viable cells in samples fermented with P. Pentosaceus M103 or L. Paracasei M104 (Table 4). After fermentation the total number of viable $L$. paracase M104 cells was 9.23 $\log _{10} \mathrm{CFU} / \mathrm{ml}$, an increase of $1.4 \log _{10} \mathrm{CFU} / \mathrm{ml}$, whereas the total number of viable $P$. pentosaceus $\mathrm{M} 13$ cells was $9.63 \log _{10} \mathrm{CFU} / \mathrm{ml}$, an increase of $1.9 \log _{10}$ $\mathrm{CFU} / \mathrm{ml}$ (Table 4).

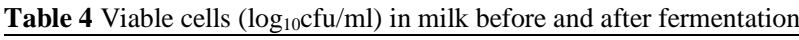

\begin{tabular}{lcc}
\hline Starter culture & \multicolumn{2}{c}{ Viable count $(\mathrm{CFU} / \mathrm{ml})$} \\
\cline { 2 - 3 }$(2 \%, \mathrm{w} / \mathrm{v})$ & $0 \mathrm{~h}$ & $10 \mathrm{~h}$ \\
\hline L. paracasei $\mathrm{M} 104$ & $7.817 \pm 0.053^{\mathrm{a}}$ & $9.238 \pm 0.330^{\mathrm{b}}$ \\
P. pentosaceus $\mathrm{M} 13$ & $7.719 \pm 0.159^{\mathrm{a}}$ & $9.637 \pm 0.510^{\mathrm{b}}$ \\
\hline
\end{tabular}

Values expressed as mean \pm standard deviation of three replicates

Means within each column with different superscript letters indicate statistically significant differences $(\mathrm{P}<0.05)$

The total numbers of viable $P$. pentosaceus M103 and $L$. paracasei M104 after fermentation were $9.637 \pm 0.510$ and $9.238 \pm 0.330 \log _{10} \mathrm{CFU} / \mathrm{ml}$ respectively; the minimum value required for functional activity in fermented milk products is $10^{6} \mathrm{CFU} / \mathrm{ml}$ (Shah, 2000). We did not evaluate the probiotic capability of $P$. pentosaceus M103 or L. paracasei M104; however several other studies have classified both species as probiotic (Kristo et al., 2003; Osmanagaoglu et al., 2013; Patrignani et al., 2009).

\section{CONCLUSION}

This study identified four species of LAB in the milk of Peranakan Etawah goats. Isolates identified as Lactobacillus paracasei M104 and Pediococcus pentosaceus M103 were shown to acidify skimmed milk effectively and had potential uses as starter culture for milk fermentation.

Acknowledgement: The authors would like to thank the Faculty of Animal Science, Universitas Gadjah Mada and Directorate General of Higher Education, Indonesian Ministry of National Education for providing research funding.

\section{REFERENCES}

AOAC INTERNATIONAL. 1995. AOAC Official Method 991. 20 Official Methods of Analysis, $16^{\text {th }}$ ed. AOAC International.

AXELSSON, L. 2004. Lactic acid bacteria: Classification and physiology, In: Salminen, S. and von Wright, A (eds) Lactic acid bacteria: Microbiology and functional aspects, 2nd ed. New York, Marcel Decker Inc., pp. 1-66. http://dx.doi.org/10.1201/9780824752033.ch1

BADAN STANDARISASI NASIONAL (1998) SNI Susu Segar (SNI 01-31411998). Jakarta. 
BADIS, A., GUETARNI, D., MOUSSA BOUDJEMA, B., HENNI, D.E., KIHAL, M. 2004. Identification and technological properties of lactic acid bacteria isolated from raw goat milk of four Algerian races. Food Microbiology, 27, 579-588. http://dx.doi.org/10.1016/j.fm.2003.11.006

BEVILACQUA, A.E., CALIFANO, A.N. 1989. Determination of organic acids in dairy products by high performance liquid chromatography. Journal of Food Science, 54(4), 1076-1077. http://dx.doi.org/10.1111/j.1365-2621.1989.tb07948.x CARRARO, L., MAIFRENI, M., BARTOLOMEOLI, I., MARTINO, M.E., NOVELLI, E. FRIGO, F., MARINO, M., CARDAZZO, B. 2011. Comparison of culture-dependent and -independent methods for bacterial community monitoring during Montasio cheese manufacturing. Research Microbiology, 162, 231-239. doi:10.1016/j.resmic.2011.01.002

CHANDAN, R.C. 2006. Manufacturing Yogurt and Fermented Milks. Iowa Blackwell Publishing Professional, 396 p. ISBN-13: 978-0-8138-2304-1. http://dx.doi.org/10.1002/9781118481301.fmatter

DE VOS, W.M., VAUGHAN, E.E. 1994. Genetics of lactose utilization in lactic acid bacteria. FEMS Microbiology Reviews, 15(2-3), 217-237. http://dx.doi.org/10.1111/j.1574-6976.1994.tb00136.x

DEL CAMPO, R., BRAVO, D., CANTÓN, R, RUIZ-GARBAJOSA, P. GARCÍA-ALBIACH, R., MONTESI-LIBOIS, A., YUSTE, F-J., ABRAIRA, V., BAQUERO, F. 2005. Scarce evidence of yogurt lactic acid bacteria in human feces after daily yogurt consumption by healthy volunteers. Applied and Environmental Microbiology, 71(1), 547-549. http://dx.doi.org/10.1128/AEM.71.1.547-549.2005

FORTINA, M.G., RICCI, G., FOSCHINO, R., PICOZZI, C., DOLCI, P., ZEPPA, G., COCOLIN L., MANACHINI P.L. 2007. Phenotypic typing, technological properties and safety aspects of Lactococcus garvieae strains from dairy environments. Journal of Applied Microbiology, 103(2), 445-453. http://dx.doi.org/10.1111/j.1365-2672.2006.03265.x

FRANZ, C., CHO, G.S., HOLZAPFEL, W.H., GALVEZ, A. 2010. Safety of lactic acid bacteria. In: Mozzi, F., Raya, R.R. \&. Vignolo, G.M (eds.) Biotechnology of lactic acid bacteria novel applications. Iowa: Blackwell Publishing, pp 341-359. http://dx.doi.org/10.1002/9780813820866.ch19

KEOGH, M.T., O'KENNEDY, B.T. 1998. Rheology of stirred yogurt as affected by added milk fat, protein and hydrocolloids. Journal of Food Science, 63(1), 108-113. http://dx.doi.org/10.1111/j.1365-2621.1998.tb15687.x

HADIWIYOTO, S. 1994. Teori dan Prosedur Pengujian Mutu Susu dan Hasil Olahannya. Liberty, Yogyakarta.

KONGO, J.M., GOMES, A.M., MALCATA, F.X. 1996. Manufacturing of fermented goat milk with a mixed starter culture of Bifidobacteriumanimalis and Lactobacillus acidophilus in a controlled bioreactor. Letters in Applied Microbiology, 42(6), 595-599. http://dx.doi.org/10.1111/j.1472765x.2006.01882.x

KRISTO, E., BILIADERIS, C.G., TZANETAKIS, N. 2003, Modelling of rheological, microbiological and acidification properties of a fermented milk product containing a probiotic strain of Lactobacillus paracasei. International Dairy Journal, 13(7), 517-528. http://dx.doi.org/10.1016/s0958-6946(03)000748

LEROY, F., DE VUYST, L. 2004. Lactic acid bacteria as functional starter cultures for the food fermentation industry. Trends in Food Science and Technology, 15, 67-78. http://dx.doi.org/10.1016/j.tifs.2003.09.004

MAKAROVA, K., SLESAREV, A., WOLF, Y., SOROKIN, A., MIRKIN, B. KOONIN, E., PAVLOV, A., PAVLOVA, N., KARAMYCHEV, V., POLOUCHINE, N., SHAKHOVA, V., GRIGORIEV, I., LOU, Y., ROHKSAR, D., LUCAS, S., HUANG, K., GOODSTEIN, D.M., HAWKINS, T., PLENGVIDHYA, V., WELKER, D., HUGHES, J., GOH, Y., BENSON, A., BALDWIN, K., LEE, J-H., DIAZ-MUNIZ, I., DOSTI, B., SMEIANOV, V., WECHTER, W., BARABOTE, R., LORCA, G., ALTERMANN, E., BARRANGOU, R., GANESAN, B., XIE, Y., RAWSTHORNE, H., TAMIR, D., PARKER, C., BREIDT, F., BROADBENT, J., HUTKINS, R., O'SULLIVAN, D., STEELE, J., UNLU, G., SAIER, M., KLAENHAMMER, T. RICHARDSON, P., KOZYAVKIN, S., WEIMER, B., MILLS, D. 2006. Comparative genomics of the lactic acid bacteria. PNAS, 103(42), 15611-15616 http://dx.doi.org/10.1073/pnas.0607117103

MARTÍN, R., JIMENEZ, E., HEILIG, H., FERNANDEZ, L., MARÍN, M.L., ZOETENDAL, E.G., RODRÍGUEZ, J.M. 2009. Isolation of Bifidobacteria from breast milk and assessment of the bifidobacterial population by PCR-denaturing gradient gel electrophoresis and quantitative real-time PCR. Applied and Environmental Microbiology, 75, 965-969. http://dx.doi.org/10.1128/aem.0206308

MOREA, M., BARUZZI F., COCCONCELLI, P.S. 1999. Molecular an physiological characterization of dominant populations in traditional Mozzarella cheese processing. Journal of Applied Microbiology, 87, 574-582. http://dx.doi.org/10.1046/j.1365-2672.1999.00855.x

OSMANAGAOGLU, O., KIRAN, F., NES, I.F. 2013. A probiotic bacterium, Pediococcus pentosaceus OZF, isolated from human breast milk produces pediocinAcH/PA-1. African Journal of Biotechnology, 10(11), 2070-2079.

PATRIGNANI, F., BURNS, P., SERRAZANETTI, D., VINDEROLA, G., REINHEIMER, J., LANCIOTTI, R., GUERZON, M.E. 2009. Suitability of high pressure-homogenized milk for the production of probiotic fermented milk containing Lactobacillus paracasei and Lactobacillus acidophilus. Journal of Dairy Research, 76(1), 74-82. http://dx.doi.org/10.1017/s0022029908003828 PIRISI, A., LAURET, A., DUBEUF, J.P. 2007. Basic and incentive payments for goat and sheep milk in relation to quality. Small Ruminant Research, 68(1-2), 167-178. http://dx.doi.org/10.1016/j.smallrumres.2006.09.009

ROBINSON, R.K. 2002 Dairy Microbiology Handbook: The Microbiology of Milk and Milk Products, 3rd Edition. New York: John Wiley \& Sons Inc, 784 p. ISBN: 978-0-471-38596-7.

SAITOU, N., NEI, M. 1987. The neighbour joining method: a new method for reconstructing phylogenetic trees. Molecular Biology Evolution, 4, 619-629. SCHWENNINGER, S.M., MEILE, L. 2004. A mixed culture of Propionibacterium jensenii and Lactobacilus paracasei subsp. paracasei inhibits food spoilage yeasts. Systematic and Applied Microbiology, 27, 229-237. http://dx.doi.org/10.1078/072320204322881853

SHAH, N.P. 2000. Probiotic bacteria: selective enumeration and survival in dairy foods. Journal of Dairy Science, 83(4), 894-907. http://dx.doi.org/10.3168/jds.s0022-0302(00)74953-8

TAMIME, A. Y., ROBINSON, R. K. 1999. Yoghurt science and technology, 2nd ed. Boca Raton: CRC Press, 791 p. ISBN 9781420044539.

TUNCTURK, Y. 2009. Influence of starter culture strains, $\mathrm{pH}$ adjustment and incubation temperature on exopolysaccharide production and viscosity in whey. African Journal of Biotechnology, 8, 4222-4228.

WIDODO, TAUFIQ, T.T., ANINDITA, N.S. 2014. Fermented goat milk and cow milk produced by different starters of lactic acid bacteria: Quality studies. Journal of Agricultural Science and Technology, A3, 904-911. 